\title{
Water Pollution Index Approaches in Spatial Planning in City Tourism Area (Case Study: Malang Area)
}

\author{
Arief Riyadi ${ }^{1}$, Arief Rachmansyah ${ }^{2}$, Bagyo Yanuwiadi ${ }^{3}$ \\ ${ }^{1}$ Master Program of Environmental Resource Management and Development, Postgraduate School, University of \\ Brawijaya, Malang, Indonesia \\ ${ }^{2}$ Department of Civil Engineering, Faculty of Engineering, University of Brawijaya, Malang, Indonesia \\ ${ }^{3}$ Department of Biology, Faculty of Mathematics and Natural Sciences, University of Brawijaya, Malang, Indonesia
}

\begin{abstract}
As a famous tourism destination in Indonesia, Malang Raya has many interesting places for visiting, like river. River becomes an important part in tourism spatial planning of a region, because almost all the waste from human activities dumped into the river, thus it will affect the quality of the river water. Malang Raya passed by 12 sub-watersheds whereas 4 of them passed 3 districts/cities, namely Metro, Bango, Amprong and Manten sub-watershed. Therefore, it needs an integrated spatial planning between the three regions, especially to support tourism destination. The purpose of this research is to formulate water carrying capacity assessment and its recommendation in spatial planning in Malang area. This is a quantitative-descriptive study using regular monitoring of water quality in 20 rivers surrounding Malang Raya by Malang Department of Environment. The results of this study show that the sub-watershed area of Metro, Bango, Amprong and Manten are classified into mild contaminated. This condition, one of them, is caused by land use changing in upstream areas. A bit more pollution in the river will affect the number of tourist visits to Malang Raya area.
\end{abstract}

Keywords: Amprong, Bango, Manten, Metro, sub-watershed, water pollution index.

\section{INTRODUCTION}

Today environmental issues are corrective discourse against the paradigm of development in Indonesia. The occurrence of the crisis on the environment increasingly clarifies the existence of biased development planning between economics growth with the environment. Economic development caused destruction of natural resources and environmental pollution. Many people considered that implementation of regional autonomy caused pollution and environmental destruction in every part of people's life [1]. Local government prioritized economic growth and override environmental conditions. Consequently, the cost of restoring the environment to the government and the community is far greater than the economic benefits it earns. The World Bank in 2007 reported that the economic costs of land damage in Indonesia amounted to US \$ 562 million. This value is smaller than air pollution damage (US \$ 5.5 billion) and water pollution, sanitation and hygiene (US $\$ 7.7$ billion) [2].

Therefore, a water carrying capacity (WCC) assessment is needed which provides recommendations for environmental improve-

\footnotetext{
*Correspondence address:

Arief Riyadi

Email : rayhanbiwiz@gmail.com

Address : Postgraduate School, University of Brawijaya, JI MT Haryono No 169, 65145 Malang.
}

ment efforts and a picture of land suitability if improvement efforts are made. In addition, WCC assessment can provide input to the evaluation of regional spatial plans (RTRW) of a region, because it contains a planning instrument that explains the relationship between humans, environment and land use [3].

This study assess the ability of the river to accommodate pollution loads with physical parameters (temperature and TSS) chemistry parameters $(\mathrm{pH}, \mathrm{BOD}, \mathrm{COD}, \mathrm{DO}, \mathrm{NH} 3, \mathrm{NO} 3, \mathrm{NO} 2$, Detergent, Oil and Grease, Total Phosphor) and biology parameters (Total Coliform and Fecal Coli) using the Water Pollution Index device (WPI). The aims of this study are formulating water pollution index (WPI) assessment in Malang area. We also give recommendations for spatial planning to support tourism program in Malang Area.

\section{RESEARCH METHOD Study Area}

We use a quantitative-descriptive assessment using regular monitoring of water quality data in 20 rivers surrounding Malang Raya area by Environmental Dept. of Malang Regency. Brantas Watershed consists of 36 subwatersheds passes 9 districts/cities in East Java Province. Of these, there are 4 sub-watersheds (DAS) pass directly through Malang Raya, as tourism area, i.e. Metro, Bango, Amprong, and Manten. 
Upstream of DAS Metro is located in Batu City, flowing eastwards through Dau sub-district (Malang Regency) turning south through west side of Malang and towards Lahor Dam in Sumberpucung Sub-district (Malang Regency). Meanwhile, the upstream of DAS Bango is located in Kecamatan Singosari and Karangploso (Malang Regency) flowing to the north side of Malang City towards the central part of the City, meeting with Amprong River flow which is upstream in Poncokusumo District (Malang Regency). Manten Watershed also has a river upstream in the southern part of Poncokusumo Sub-district passing through the central part of Malang Regency and ends, along with the Amprong River and Bango, at the Karangkates Dam.

\section{Sampling Point}

Environmental Dept. of Malang District always conduct regular water quality monitoring to 30 rivers which is covered 6 sub watersheds which is 4 sub watershed matches with this area of study (Supplementary 1). Location of water sampling is designed from upstream to downstream in order to know the tendency of water pollution along river. This recommendation will be used by Environmental Dept. of Malang District (DLH) as input in arranging program to control water contamination along stream monitored. For two years, DLH has taken six times sampling, twice in 2016 (March and June) and four times in 2017 (March, May, July and September. Finally, the results compared by analysis during the rainy and dry seasons.

\section{Data Analysis Water pollution index}

The Water Pollution Index are used to determine the level of pollution relative to the allowed water quality parameters [4]. WPI is determined from resultant maximum value and mean value of each parameter concentration ratio to its standard value, following this equation.

$$
P_{i j}=\sqrt{\frac{\left(C_{i} / L_{i j}\right)_{M}^{2}+\left(C_{i} / L_{i j}\right)_{R}^{2}}{2}}
$$

Determination of water pollution status described as follows [4]:

$$
\begin{aligned}
& 0 \leq \mathrm{P}_{\mathrm{ij}} \leq 1.0 \text { Good condition } \\
& 1.0<\mathrm{P}_{\mathrm{ij}} \leq 5.0 \text { Mild Contaminated } \\
& 5.0<\mathrm{P}_{\mathrm{ij}} \leq 10 \text { Medium Contaminated } \\
& \mathrm{P}_{\mathrm{ij}}>10.0 \quad \text { Severe Contaminated }
\end{aligned}
$$

\section{Correlation of water quality and rainfall}

We analyzed the correlation between water quality in the river and rainfall occurring at the time of water sampling. In this case, we use Pearson Product Moment (PPM) approaches as follows [5]:

$$
r=\frac{N \Sigma x y-\Sigma x \Sigma y}{\sqrt{N \Sigma x^{2}}-(\Sigma x)^{2} \sqrt{N \Sigma y^{2}}-(\Sigma y)^{2}}
$$

Description:

$r=$ coeff. Correlation of Pearson Product Moment

$\mathrm{N}=$ number of $\mathrm{x}$ and $\mathrm{y}$ data pairs

The pattern or form of relationship between two variables can be positively or negatively correlated. If the value of the correlation coefficient is close to the value of +1 , then the $x$ and $y$ data pair are strongly positive linear correlates and vice versa. The strength correlation between $\mathrm{x}$ and $\mathrm{y}$ follows the criterion formula in Table 2.

Table 2. Criteria of Correlation

\begin{tabular}{cc}
\hline Coeff. Corelation $r$ & Interpretation \\
\hline $0.8-1.0$ & Very High \\
$0.6-0.8$ & High \\
$0.4-0.6$ & Moderate \\
$0.2-0.4$ & Low \\
$0.0-0.2$ & Very Low \\
\hline Source: Guilford (1956) [5]
\end{tabular}

\section{RESULT AND DISCUSSION}

\section{Water Pollution Index in Metro Sub watershed}

The results of analysis conducted in 2016 at all sampling point shown that status of the water quality of the Metro Sub watershed is mild contaminated. The same results are shown in 2017, at the same location of sampling, i.e. mild contaminated. In Figure 1, it can be seen that mild contaminated status for each river is very volatile with sampling time. Previous research revealed that the quality of river water from upstream to downstream that has changed from good to mild contamination [6].

In the upstream of the Metro River, the performance of Metro sub watershed is poor [7]. This condition is caused by the vegetation area only $57.92 \%$. The expansion of settlements is the cause of the reduced extent of vegetation. 
Reduced vegetation area causes triple surface runoff up to 12 times (2002 - 2014).

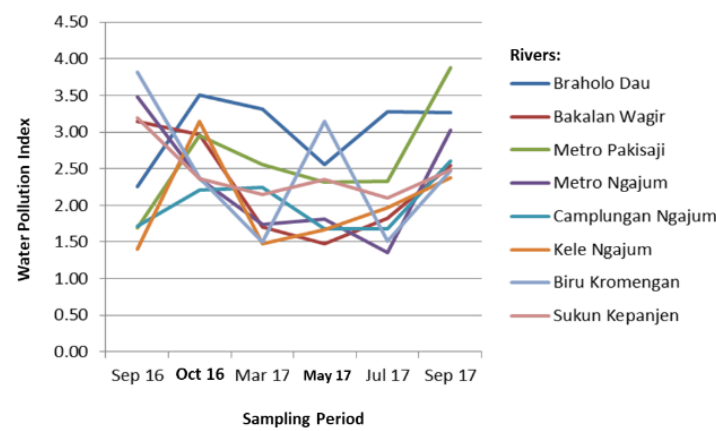

Figure 1. Water Quality Status of Rivers in Metro Sub watershed during 2016-2017

In the downstream, the poor quality of river along the Metro River is indicated by high levels of COD. The high levels of COD are presumed to be due to factories disposing of waste in Metro River [8]. These factories are produce of organic waste that are difficult to degrade naturally, such as leather, rubber, paper, and tapioca flour mills. These degradable organic wastes cause high COD values at most points of water sampling. In addition, poor water quality also caused by the waste that comes from animal slaughterhouses, jelly, cigarette, and pig farms along Metro River.

\section{Water Pollution Index in Bango Subwatershed}

The results of analysis conducted in 2016 at all sampling points shown that status of the water quality of the Bango Subwatershed is mild contaminated. The same results are shown in 2017, at the same location of sampling, i.e. mild contaminated as shown in Figure 2.

The poor water quality along Bango and Amprong rivers are caused by the changed land covering during 1999-2013 [9]. It can trigger land erosion, raising runoff debit and decreasing water quality. Finally, caused low performance of sub watershed. In addition, changed on land covering decrease the water quality in water springs surround the sub watershed. Eight springs in Karangploso (Bango sub watershed area), namely PraNyolo, Ngenep, Umbulan, Langgar, Balittas, Lowoksari, Leses and Soko) indicated that it is not suitable to be used as raw drinking water based on Government Regulation No. 82/2001 on Water Quality Management and Water Pollution Control [10]. The most visible indications are the levels of DO (all springs), nitrite (PraNyolo spring) and nitrate (Langgar, Balittas, Lowoksari, Leses, Soko springs) which were below the established standard. Even the toxic contaminants' level of pollution is higher according to the Shannon-Wiener index, the level of organic matter contamination decreases in the channel along with the progressive way from the springs [11].

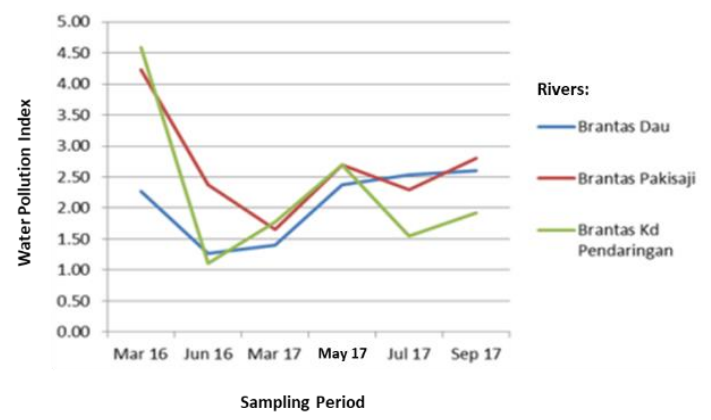

Figure 2. Water Quality Status of Rivers in Bango Sub watershed during 2016-2017

The same conditions in Singosari shown that human activities occurring in the channel of Sumberawan, i.e. agriculture, livestock, settlement and toilets have affected the water quality. It was seen from the decreasing of water quality from upstream to downstream. The indicator that emerges is a change in benthic macroinvetebrate community structure along the channel up to approximately $800 \mathrm{~m}$ from springs $[12,13]$.

\section{Water Pollution Index in Amprong Sub watershed}

The results of analysis conducted in 2016 at all sampling points shown that status of the water quality of the Amprong Subwatershed is mild contaminated. The same results are shown in 2017 (Fig. 3). Only one sample was shown below the established standard. The sample was taken from June 2016 in Amprong River, Poncokusumo.

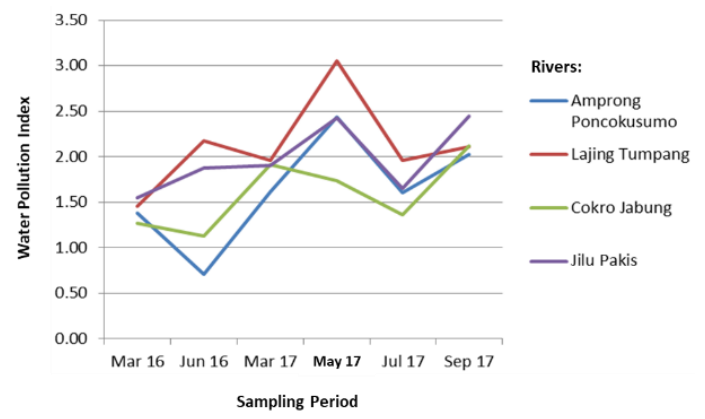

Figure 3. Water Quality Status of Rivers in Amprong Sub watershed during 2016-2017

Water Pollution Index in Manten Subwatershed

The results of analysis conducted in 2016 at all sampling point locations shown that the water quality in Manten Sub watershed is mild 
contaminated, as well as the results in 2017 (Fig. 4). However, two samples were shown below the standard. The sample was taken from September 2016 in Brantas River, i.e. Kecopokan and Sumberpucung.

Water Pollution Index analysis showed that in Manten Sub-watershed, there are two samples has value below the established standard. It is likely due to low rainfall in June and September where the sample is taken. At low rainfall (dry season), there is no rain flow that carries organic material, so that the quality of water measured below the established standard.

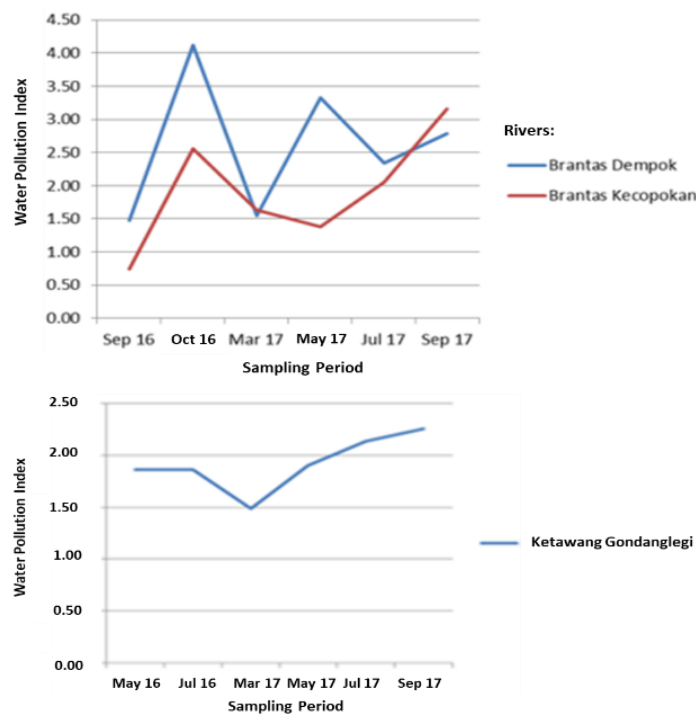

Figure 4. Water Quality Status of Rivers in Manten Sub watershed during 2016-2017

\section{Correlation of Water Quality and Rainfall}

The correlation between rainfall and quality status of river is shown in Table 3. Only two rivers (Brantas Dempok and Brantas Dau) shown that rainfall has high relationship with water quality in negative linear correlates. Brantas River in Dempok located in downstream and Brantas River in Dau located in Upstream. It is concluded that the most water quality in the rivers have no relationship with rainfall.

In general, observations of 13 parameters tested showed that only TSS, DO, BOD, COD and nitrite that greatly affected the quality of river water. Other parameters measured are still below the quality standards required in Regional Regulation No. 2 of 2008 on Water Quality Management and Water Pollution Control in East Java Province Class II. Thus, it is not affected the measurement on quality of river water.

High concentrations of TSS affect turbidity and clarity of water so that it will affect the process of photosynthesis. Finally, it will affect the process of purification in natural water (selfpurification) because the process of photosynthesis was inhibited [8]. In other hand, low DO levels indicate the presence of contamination of organic matter within the river. Human activities such as agriculture and waste disposal causing decrease of DO [14].

\begin{tabular}{lc}
\multicolumn{2}{c}{ Table 3. Coefficient Corelation of PPM in each River } \\
\hline River & Coeff. Corelation \\
\hline Braholo Dau & -0.00147172 \\
Bakalan Wagir & -0.23758466 \\
Metro Pakisaji & -0.274 \\
Metro Ngajum & -0.470 \\
Camplungan Ngajum & -0.073 \\
Kele Ngajum & -0.484 \\
Biru Kromengan & -0.599 \\
Sukun Kepanjen & -0.498 \\
Kali Curah Singosari & -0.130 \\
Kalibodo Ngijo & 0.279 \\
Amprong Poncokusumo & -0.372 \\
Lajing Tumpang & -0.378 \\
Cokro Jabung & -0.008 \\
Jilu Pakis & -0.411 \\
Brantas Dau & -0.757 \\
Brantas Pakisaji & -0.278 \\
Brantas Kd Pendaringan & 0.045 \\
Ketawang Gondanglegi & 0.127 \\
Brantas Dempok & -0.849 \\
Brantas Kecopokan & -0.567 \\
\hline Source: Result Analysis, &
\end{tabular}

Source: Result Analysis, 2017

High BOD value is caused by waste disposal from settlement and farmland [15]. Meanwhile, High level of COD indicates the greater level of pollution [16]. Those are likely to be caused by industrial waste discharges that surround the river [8].

\section{RECOMMENDATION}

It needs serious efforts from 3 stakeholders in Malang Raya to make the river better in other to support tourism in aspects:

1) Spatial Planning

a. Added Green Open Space (RTH), based on regulation of the minister of public works no. 5/2008. There are 2 type of RTH, private (10\%) and public (20\%).

b. Fulfillment of domestic wastewater treatment facilities should be in line with population growth rates and its distribution [17].

c. Structuring of settlements around riverbanks and other slums area.

2) Policies and Regulation

a. Withstand the rate of land-use changing by arranging regulations for the development of horizontal housing 
b. Supervision and evaluation on the performance of industrial waste treatment plants located around the river [18].

c. Law enforcement coupled with economic and financial policies that encourage industries to implement preventive waste reduction efforts from their sources [17].

d. Harmonization by all parties in waste water management planning with socioeconomic aspects $[19,20]$.

3) Technical

a. Water Replenish Program by: constructive conservation, i.e. making absorption wells, and check dam or catchment, eco-drainage and biopore holes.

b. Water Use Savings by: domestic wastewater treatment and reuse, implement progressive tariffs, recognizing technical and non technical leakage, reward and punishment to water customers

c. Vegetative Conservation. This type of conservation is suitable for plantation and forest land, or in protected areas around the spring with a radius of more than $200 \mathrm{~m}$ [15]

d. Mechanical Conservation. This type of conservation is all physical, mechanical and building work done on the ground, aimed at reducing run-off, erosion and improving the soil's ability class [17].

4) Public and Private Involvement

a. Increasing environmental awareness and education to the community through inserting water management in school curricula, involving community in conservation program, Strengthening institutions in the community regarding environmental management by synergic coaching, training, extension and counseling together with local organization organizations, NGOs and other donor agencies

b. Involving private sector in conservation, especially in the management of CSR funds (Corporate Social Responsibility) directed to environmental issues

c. Development of Tourism Village around Conservation Area

\section{CONCLUSION}

Water quality of 20 rivers in 4 sub watershed which pass directly through Malang Raya, as tourism area, i.e. Metro, Bango, Amprong, and Manten show mild contaminated status, based on the water pollution index.

\section{ACKNOWLEDGEMENT}

This study is part of the providing documents Environment Quality Index (IKLH) in 2017 funded by Environment Dept (DLH) of Malang District. We deliver many thanks for the Head of DLH and all staffs.

\section{REFERENCES}

[1] Wijoyo, S. 2005. Otoda: dari mana dimulai. Airlangga University Press. Surabaya.

[2] Anonim. Investing In A More Sustainable Indonesia. Report No. 50762 - ID, World Bank. 2007.

[3] Brontowiyono, W. 2016. Kajian Lingkungan Hidup Strategis untuk RTRW dengan pendekatan daya dukung lingkungan. Andi Publisher. Yogyakarta.

[4] Nemerow, N. L. and H. Sumitomo. 1970. Benefits of water quality enhancement. Report No. 16110 DAJ, prepared for the U.S. Environmental Protection Agency. December 1970. Syracuse University, Syracuse, New York, United States.

[5] Muttaqin, A., Tukiyat, Purwadi and T. H. Seto. 2014. Korelasi antara data curah hujan penakar manual dan TRMM (Tropical Rainfall Measuring Mission) Giovanni Tovas. (studi kasus teknologi modifikasi cuaca untuk menanggulangi kabut asap kebakaran hutan dan lahan di Riau tahun 2014). Jurnal Sains \& Teknologi Modifikasi Cuaca 15(2), 51-56.

[6] Mahyudin, Soemarno and T. B. Prayogo. 2015. Analisis kualitas air dan strategi pengendalian pencemaran air Sungai Metro di Kota Kepanjen Kabupaten Malang. Jurnal Pembangunan dan Alam Lestari 6(2), 105114.

[7] Harifa, A. C., M. Solichin and T. B. Prayogo. 2017. Analis pengaruh perubahan penutupan lahan terhadap debit sungai Sub DAS Metro dengan menggunakan program ARCSWAT. Jurnal Teknik Pengairan 8(1), 114.

[8] Yetti, E., D. Soedharma and S. Haryadi. 2011. Evaluasi kualitas air sungai-sungai di kawasan DAS Brantas Hulu Malang dalam kaitannya dengan tata guna lahan dan 
aktivitas masyarakat di sekitarnya. Jurnal Pengelolaan Sumberdaya Alam dan Lingkungan 1(1), 10-15.

[9] Akbari, F. R. 2014. Analisa perubahan tutupan lahan di Daerah Aliran Sungai dengan menggunakan klasifikasi terbimbing dan Algoritma NDVI pada Citra LANDSAT 8 (Studi Kasus: Sub Daerah Aliran Sungai Ambang Hulu, Kabupaten Malang). Department of Geomatics Engineering. Bachelor Thesis. Sepuluh Nopember Institute of Technology. Surabaya.

[10] Rahmawati, N. N. and C. Retnaningdyah. 2015. Struktur komunitas makroinvertebrata bentos di saluran Mata Air Nyolo Desa Ngenep Kecamatan Karangploso Kabupaten Malang. Jurnal Biotropika 3(1), 21-26.

[11] Rahmawati, R. and C. Retnaningdyah. 2015. Studi kelayakan kualitas air minum delapan mata air Di Kecamatan Karangploso Kabupaten Malang. Jurnal Biotropika 3(1), 50-54.

[12] Habiebah, R. A. S. and C. Retnaningdyah. 2014. Evaluasi kualitas air akibat aktivitas manusia di Mata Air Sumber Awan dan Salurannya, Singosari Malang. Jurnal Biotropika 2(1), 40-45.

[13] Mariantika, L. and C. Retnaningdyah. 2014. Perubahan struktur komunitas makroinvertebrata bentos akibat aktivitas manusia di saluran Mata Air Sumber Awan Kecamatan Singosari Kabupaten Malang. Jurnal Biotropika 2(5), 254-259.

[14] Blume, K. K., J. C. Macedo, A. Meneguzzi, L. B. Silva, D. M. Quevedo and M. A. S. Rodrigues. 2010. Water quality assessment of the Sinos River, Southern Brazil. Journal of Biology 70, 1185-1193.

[15] Anhwange, B. A., E. B. Agbaji and E. C. Gimba. 2012. Impact assessment of human activities and seasonal variation on River Benue, within Makurdi Metropolis. Journal of Science and Technology 2, 248254.

[16] Yudo, S. 2010. Kondisi kualitas air Sungai Ciliwung di Wilayah DKI Jakarta ditinjau dari parameter organik, amoniak, fosfat, deterjen dan bakteri Coli. Jurnal Akuakultur Indonesia 6, 34-42.

[17] Kustamar, B. Parianom, G. Sukowiyono and Tutik Arniati. 2010. Water source conservation based upon community's participation in Batu Town, East Java. Dinamika Teknik Sipil 10(2), 144-149.
[18] Qin, H. P., Q. Su., S. T. Khu and N. Tang. 2014. Water quality changes during rapid urbanization in the Shenzhen River catchment: an integrated view of socioeconomic and infrastructure development. Sustainability Journal 6, 7433-7451.

[19] van den Hurk, M., E. Mastenbroek and S. Meijerink. 2014. Water safety and spatial development: an institutional comparison between the United Kingdom and the Netherlands. Land Use Policy 36, 416-426.

[20] Nielsen, H. O., P. Frederiksen, H. Saarikoski, A. Rytkonen and A. B. Pedersen. 2013. How different institutional arrangements promote integrated river basin management: evidence from the Baltic Sea region. Land Use Policy 30, 437-445. 
Supplementary 1. Sampling Location Source: DLH of Malang District, 2016-2017

\begin{tabular}{|c|c|c|c|c|}
\hline No & Location & 2016 & 2017 & $\begin{array}{l}\text { Sub } \\
\text { watershed }\end{array}$ \\
\hline 1 & DAM Sengkaling - Brantas River, Dau District & \multirow{9}{*}{$\begin{array}{l}\text { - March 14-15 } \\
\text { - June } 15-16\end{array}$} & \multirow{9}{*}{$\begin{array}{l}\text { - March } 7 \\
\text { - May } 8 \\
\text { - July } 17 \\
\text { - September } 4\end{array}$} & Manten \\
\hline 2 & Curah Dengkol River, Singosari District & & & Bango \\
\hline 3 & Bodo River, Ngijo Village, Karangploso District & & & Bango \\
\hline 4 & Jilu River, Pakis District & & & Amprong \\
\hline 5 & Cokro River, Jabung District & & & Amprong \\
\hline 6 & Lajing River, Tumpang District & & & Amprong \\
\hline 7 & Amprong River, Poncokusumo District & & & Amprong \\
\hline 8 & Brantas River, Pakisaji District & & & Manten \\
\hline 9 & Brantas River, Kdpendaringan, Kepanjen District & & & Manten \\
\hline 10 & Ketawang River, Gondanglegi District & $\begin{array}{l}\text { - May } 16-17 \\
\text { - July } 13\end{array}$ & \multirow{11}{*}{$\begin{array}{l}\text { - March } 9 \\
\text { - May } 10 \\
\text { - July } 18 \\
\text { - September } 5\end{array}$} & Manten \\
\hline 11 & Brantas River, Kecopokan Village, Sumberpucung District & \multirow{10}{*}{$\begin{array}{l}\text { - September 5-6 } \\
\text { - October } 13\end{array}$} & & Manten \\
\hline 12 & Sukun River, Kepanjen District & & & Metro \\
\hline 13 & Brantas River, Dempok Village, Pagak District & & & Manten \\
\hline 14 & Biru River, Kromengan District & & & Metro \\
\hline 15 & Kele River, Ngajum District & & & Metro \\
\hline 16 & Camplungan River, Ngajum District & & & Metro \\
\hline 17 & Metro River, Ngajum District & & & Metro \\
\hline 18 & Metro River, Pakisaji District & & & Metro \\
\hline 19 & Bakalan River, Wagir District & & & Metro \\
\hline 20 & Braholo River, Dau District & & & Metro \\
\hline
\end{tabular}

